\title{
Developing a Conceptual Model of Cultural Policy- making in District 8 Payame Noor Universities based on Piety
}

\section{Desarrollar un modelo conceptual de formulación de políticas cul- turales en las universidades del Distrito 8 Payame Noor basado en Piety}

Fatemeh Shahabi Nejad

Islamic Azad University, Kerman, Iran. ORCID: https://orcid.org/0000-0003-1664-0945

Hamdollah Manzari Tavakoli

Islamic Azad University, Kerman, Iran. ORCID: https://orcid.org/0000-0003-1651-3663

Mohammad Jalal Kamali

Islamic Azad University, Kerman, Iran.

ORCID: https://orcid.org/0000-0002-4501-6212

\section{Sanjar Salajegheh}

Islamic Azad University, Kerman, Iran.

ORCID: https://orcid.org/0000-0002-3412-6731

\section{Hamid Reza Molaei}

Islamic Azad University, Kerman, Iran.

ORCID: https://orcid.org/0000-0002-0978-1953

Received 06-14-20 Revised 08-10-20 Accepted 09-01-20 On line 09-30-20

*Correspondence

Email: H_manzardi33@yahoo.com
Cite as:

Shahabi Nejad, F., Manzari Tavakoli, H. Kamali MJ., Salajegheh S., \& Molaei, HR. Developing a Conceptual Model of Cultural Policy-making in District 8 Payame Noor Universities based on Piety. Propósitos y Representaciones, 8 (SPE3), e763. Doi: http://dx.doi.org/10.20511/pyr2020.v8nSPE3.763 


\section{Summary}

The present study aimed to provide a conceptual model of cultural policy-making in Payame Noor universities in District 8 based on piety and virtue. In this study, the components of cultural policy based on piety were first identified through exploratory studies and surveys of knowledge-aware experts using the Delphi technique, and then these factors were tested in the form of a model designed in the statistical population. The statistical population of the study was 30 experts to test the model and to measure the research variables according to the managers of District 8 Payame Noor University; the head of cultural affairs of the university and clerics and professors of Islamic education department of Payame Noor Universities District 8 were used, which were 110 individuals. Due to the limited statistical population, the census method was used. The present study is a descriptive-correlational research that has been done by survey method. Furthermore, this research is development-applied in terms of purpose. The data collection method in this study is a combination of library and field studies and the tools of data collection are review of documents, interviews and questionnaires, which confirmed the validity and reliability of the questionnaires. In order to analyze the data, descriptive statistics (types of indicators, statistical tables and graphs) and inferential statistics (structural equation modeling) have been used. The research findings, while confirming the proposed model of research, showed that piety and its components: God-centeredness and monotheism, promoting the need to obey divine sovereignty, expediency in Islamic culture and meritocracy (Imam Ali's biography) have a positive and significant effect on cultural planning. At the end, research suggestions were presented.

Keywords: Policy, Cultural Policy, Islamic Management.

\section{Resumen}

El presente estudio tuvo como objetivo proporcionar un modelo conceptual de formulación de políticas culturales en las universidades Payame Noor en el Distrito 8 basado en la piedad y la virtud. En este estudio, los componentes de la política cultural basada en la piedad se identificaron primero a través de estudios exploratorios y encuestas de expertos conscientes del conocimiento utilizando la técnica Delphi, y luego estos factores se probaron en forma de un modelo diseñado en la población estadística. La población estadística del estudio fue de 30 expertos para probar el modelo y medir las variables de investigación según los gerentes de la Universidad Payame Noor del Distrito 8; Se utilizaron el jefe de asuntos culturales de la universidad y los clérigos y profesores del departamento de educación islámica del Distrito 8 de las Universidades Payame Noor, que fueron 110 personas. Debido a la población estadística limitada, se utilizó el método del censo. El presente estudio es una investigación descriptivacorrelacional que se ha realizado mediante un método de encuesta. Además, esta investigación se aplica al desarrollo en términos de propósito. El método de recolección de datos en este estudio es una combinación de estudios de biblioteca y de campo y las herramientas de recolección de datos son la revisión de documentos, entrevistas y cuestionarios, que confirmaron la validez y confiabilidad de los cuestionarios. Para analizar los datos, se han utilizado estadísticas descriptivas (tipos de indicadores, tablas estadísticas y gráficos) y estadísticas inferenciales (modelos de ecuaciones estructurales). Los resultados de la investigación, al tiempo que confirmaron el modelo de investigación propuesto, mostraron que la piedad y sus componentes: centrado en Dios y el monoteísmo, promoviendo la necesidad de obedecer la soberanía divina, la conveniencia en la cultura islámica y la meritocracia (biografía del Imam Ali) tienen un efecto positivo y significativo. en planificación cultural. Al final, se presentaron sugerencias de investigación.

Palabras clave: Política, Política Cultural, Gestión Islámica. 


\section{Introduction}

Since 1970s, those involved in economic and social development concluded that no development will be provided without cultural development and the issue of cultural management was studied precisely and at UNESCO, and gradually theories of cultural management were codified. On the other hand, one of the main tasks of the governments and, consequently, the government of the Islamic Republic, is how they interact with issues that occur in various social fields. One of the main fields in current societies is the area of culture, which especially in the Islamic Republic of Iran has always faced many problems and issues (Komilifard et al., 2017). Of course, in scientific research, in order to work in the field of culture and to improve and promote it in the Islamic Republic of Iran, various dimensions have been considered, so that each researcher has looked at the issue of culture from different points of view during the Islamic Revolution and in order to promote culture in the society, they know something that others have approved or rejected.

Although policy-making is an old task, it is introduced as a new specialty and profession. In policy analysis, Druro explains both the process of its shaping and adjusting the content of the policy. In discussing the process of shaping the policy, understanding the policy and the methods of participation in its formulation are considered, and in discussing the content of the policy, the results of the policy options are analyzed through cost-benefit analysis and issues such as distribution of benefits are examined (Poor Ezat, 2014).

\section{Theoretical Foundations of Research:}

The literal meaning of policy is the articles of association, code of conduct, method and procedure. The first word that comes to mind from policy is politics (Smith Kevin \& Christopher, 2009). However, sometimes the meaning of a word is not inferred directly from the word itself, such as the word motivation, which is often used in management instead of purpose, intention and determination, but in Arabic it means stimulus (driver) and movement lies within it (Mohammadi Gharasoui, 2013).

Policy-making as a cycle is a process involving several activities and steps. It is obvious that these steps do not take place mechanically and separately, but are formed as a dynamic and multi-faceted process. Experts generally classify these phases into three stages of formulation, implementation and evaluation and believe that implementation may be the most important of these stages, so that some even call it a missing link in the policy process (Goldar et al., 2017).

A policy is a general plan that, as a guide to action, is considered by managers and determines how the plan should be implemented by the organization's executives; while it is an effective tool to control operations (Rezaian, 2011). The steps are explained below:

Problem seeking: The initial stage is problem solving which is started from the definition of the problem, to define the problem, environmental research begins using analysis techniques and the data and information in the receiving environment are analyzed. Timely recognizing of issues and opportunities even before they occur, is critical (Alvani \& Sharifzadeh, 2011).

Policy formulation: At this stage, the organization in relation to the goals and mission of the public organization, conducting studies and having expertise view, socio-economic-cultural status, obligations and responsibilities, analyzes and examines the values governing society and other related factors, issue or problem. The effort of the employees of the organization in achieving the desired options and solutions to solve the problem, takes by considering all aspects of the problem with the formation, preparation and formulation of public policy and it is necessary to provide legal or written rules and principles for implementation (Alvani et al., 2014).

Policy approval: After analyzing the results of each solution, it is possible that through comparison selects the best way and present as a desirable policy (Alvani et al., 2014).

Policy implementation: Many issues affect the optimal and effective implementation of the policy, program or plan such as access to financial resources, efficient human resources, equipment, information, familiarity of the executives with the spirit and content of the policy and understanding and recognizing the problem for which the solution has been formulated and 
approved, and the way of controlling and monitoring the proper implementation of the program, plan or policy, etc. (Alvani \& Sharifzadeh, 2011).

Policy evaluation: In this regard, the goals, missions, intentions and strategies of the organization and the problem felt by citizens can be a guide for managers in this important case that while achieving the goals of the organization was able to solve the client problem in general. In addition, responding to the above problem has not led to the formation of a new issue in the organization and outside and not creates future problems for those involved in the policy (Alvani et al., 2014).

Cultural policy: Some scholars have defined cultural policy as conscious action in the realm of culture that is mainly adopted by governments. Cultural policy is, in fact, public policy in the field of culture. The correct premise is hidden in the term that the realm of culture is one of the realms of public policy, but the fact is that it is very difficult, if not impossible, to distinguish between different areas of policy. Culture is one of the dimensions of social reality and public policy has a cultural dimension since it is related to social realities, but depending on various issues, this cultural dimension can be bolder or lighter (Khanifar \& Agdaghi, 2015).

\section{Piety and Virtue in Islamic Management}

When you look at the history your ancestors, you will not find people who lived without a leader, boss or manager. This historical fact is the best proof of the necessity of management. From the beginning of the management formation, theories of management and organization have been applied without being codified and systematic, and its application is evident in the descriptions and actions of apostles, commanders and elders in the past ages. However, management theories are not a new phenomenon that human beings have achieved in the new era, but what has been done in the field of organization and management in recent centuries is collecting and implementing scattered theories and ideas that already exist. God says in the Holy Quran in Surah Ar-Rum (The Romans),"And one of his signs is that he created you from dust, then, suddenly you were human beings dispersing throughout the earth".

After creating human, we come to the point that God has created a world of this greatness for human beings. As he says in Surah Al-Mu'minun, "And we have created above you seven layered heavens, and never have We been of our creation unaware", "We sent down water from the sky in a measured manner, and we lodged it within the ground, and we are indeed able to take it away", "Then with it We produced for you gardens of date palms and vines. There are abundant fruits in them for you, and you eat from them", (Afjeh et al., 2014). In Islam, management is moving toward God. In other words, piousness and piety are practiced at all levels, efforts for forgiveness and guidance increase and considering the satisfaction of the majority increases (Askarian, 2011).

Piety is consisted of the following dimensions:

God-centeredness and monotheism: The first feature of Islamic culture is its Godcenteredness. "Say: There is no god Except Allah to be successful " has been proposed as the first value and the first order of the Prophet of Islam. It certainly does not mean saying some words, rather, it means to make it as a life lesson and its best manifestation is in culture and all cultural activities should be done on its basis (Zeraat, 2017).

Promotion the necessity of obeying divine sovereignty: It is not possible to command with an irregular framework. The Quran considers the management of the universe just for one creator and considers the harmony and unity of the world as the will of God. Accordingly, due to the presence of different votes and opinions in the organization, coordination between individuals and unity of procedure should be constantly followed so that there is no inconsistency and conflict of tasks.

Policy in Islamic culture: In the field of culture, good choices instead of better ones are catastrophic, not to mention wrong choices. Therefore, one of the cultural needs is policy (expediency). This criterion is also found well in the life of Imam Ali. Imam Ali when faced with usurpation of his right by some people, he did not have any choices but to be patient in order to 
preserve the new Islamic society and the interests. It is an action that shows the depth of expediency in the life of Imam Ali (Zeraat, 2017).

Meritocracy: $\mathrm{O}$ people the most deserving people for the caliphate is the one who is stronger in the fulfillment of the government and more knowledgeable in the God's command" (Tamimei Amedi, 1980).

\section{Literature Review}

(Gorbanizadeh et al., 2017) in a study presented the policy making model of cultural organizations (Case study: Institute for the Intellectual Development of Children and young adults). The results of the present study, in addition to drawing the pattern of policy making in the mentioned organization, also analyzes and explains the process of policy making in Iranian cultural organizations.

(Komilifard et al., 2017) in a study examined and analyzed the steps of the cultural policy-making system in the Islamic Revolution of Iran. In this research, by enumerating and extracting the main stages in the cultural policy-making process, an attempt has been made to prioritize the stages of the policy-making process based on two dimensions of the importance of each stage in the policy-making process and the performance of the policy-making system. Finally, in this study, the stages of problem recognition and understanding, evaluation and implementation were identified as the first priorities for improvement in the cultural policy-making process, respectively. In addition, matrix-based analysis explains the importance and performance of the policy-making process with serious recommendations for improvement in the cultural policy-making process.

(Sakaran, 2011) in a study examined the conditions for effective implementation of the policy and found that the conditions for effective implementation of the policy are: 1. Clear goals; 2. Causal relations and having a theoretical basis; 3. A stabilizer and a leader, with political and managerial skills; 4. Supporting policies by legislators, executive authorities, judicial authorities and target groups; 5. Paying attention to economic, social and international conditions.

(Bardach, 1997), found that ways to force groups and players to participate in policy implementation include: incitement, dealing, bargaining, encouragement and persuasion and persuasion, and some tricks and games performed by policy executives to prevent correct policy implementation. These include: budget gaming, peacekeeping, collective resistance, easy and comfortable life and other games.

(Makinde, 2010) in a study identified the factors of performance failure and found that the factors of performance failure are insufficient communication and information, lack of sufficient resources and facilities, tendencies, motivations and attitudes of performers, performers' evaluations of policy implementation (conflict between implementation and their interests), the emission of a policy by the government instead of the target groups, and ignoring the social, political, economic and administrative variables.

(Konsult, 2009) identified barriers to implementation and there are as following: 1. Legal and institutional barriers; 2. Financial barriers; 3. political and cultural barriers.

Theoretical Framework of Research, Conceptual Model and Questions

The theoretical framework is a conceptual model based on the theoretical relationships between a numbers of factors that have been identified as important in the research problem (Sakaran, 2011). In this research, Islamic management has been considered as a criterion variable and general policy-making has been introduced as a predictor variable.

There are different patterns and theories from the past literature of policy-making. Whether these patterns and frameworks can be used exactly in the policy of Islamic governments which one of its main elements is adherence to the original and vital teachings are the main issue and the main question of this research. Policies are the manifestation of governments' fundamental orientations in practice. Furthermore, policy-making is the most fundamental manifestation of the existence of governments in the field of decision-making and implementation. Due to the wide range of decisions and policies, the more compatible this is with human nature and the dynamics of the environment, the more efficient and effective it will be in managing public 
affairs in Islamic governments. In the new era, the issue of culture has become much more complex than in the past. In the past, culture was such a tradition, ethnic and local whose values stemmed from religion. The thoughts and ideas of the people were manifested in a certain range as the form of different cultural productions. Today, due to the extension of technology and mass media, which has enabled cultural invasion, cultures are intertwined and each culture is present in different places at the same time. Cultural tastes have undergone many changes and tastes are widely developed in the world in a dense manner. The new culture is a culture that in addition to its instability and impulses must also preserve spontaneities, traditions and cultural originality. Therefore, cultural management is not simple. Do we have an institution that trains the director of cultural affairs in its own sense? Our problem today is that we want to voluntarily and instructively apply and spread culture in our society and in different social groups. But what plans, programs and strategies have we considered for this issue? Till this strategy does not exist and there are no people involved who have a good understanding of this strategy and can implement it at the management level, no change will occur (Ghoshal, 2005). Cultural planning is a relatively new term that emerged in Europe in the 1960s and 1970s, in which the formulation of cities changed geographically and economically, and in line with the strategy of reviving and reconstructing part of European cities, the arts took root in local culture and it was cohesive within cities based on the basics of daily urban life. Today, all societies strongly recommend cultural planning and development. The history of cultural planning can also be traced in ancient Greece.

Culture is one of the most important and vital areas in any society that has been considered by the elite and authorities. The cultural sphere is strongly tied to other social, economic and political domains. Some consider culture to be the influential core of society, which also affects how other areas are formed. The Supreme Leader of the Revolution has repeatedly mentioned this important point: "Culture is like climate. Culture means the same customs and traditions that govern my life and yours. Culture means our beliefs and things that personal and social life and inside the home and the environment of a society will face (Amadi, 2006). This serious matter has caused the elites and officials of the society to be sensitive to culture and the issue of making the necessary changes to direct it towards the desired situation is always one of their concerns. This is reflected in the form of cultural management and policy-making. However, in this field, there is a wide range of theories that in any society different from other societies, attention has been paid to intervention or non-interference in culture. The subject of culture has various and wide dimensions in which several components are influential. A serious concern in cultural policy-making is always to have a strategic view in this regard and to find bottlenecks and leverage points that relying on them can create the necessary convergence in other components of culture (Goldar et al., 2017).

Monotheistic culture is achieved through the establishment of justice and the implementation of Islamic rules. The cultural tradition and method of Imam Ali is the same as the cultural practical behavior of the Prophet and the Imam acted according to this tradition from the very beginning of his governing. Islam prefers the natural dimension, which is the soul and spirit (mental), over the instinctive or physical dimension, and it is the difference between man and animal (Ayoubi, 2010). The most important issue is the inherent dignity of man, blood, hereditary and racial issues have no role in his dignity, which can be seen in the companions of the Prophet who were from different social classes. The second basis in the cultural behavior of Imam Ali is piety and piety and from Imam's point of view, a culture that leads to monotheism is considered important, in other words, the evaluation of human beings is based on the two principles of monotheism and the human dimension of a person. Monotheistic culture creates suitable grounds for this culture by providing basis for development such as the establishment of justice, the realization of rights and the implementation of Islamic rules, the ranking of human beings or the distribution of government positions based on piety and equality. Culture is created easily when there are appropriate tools and contexts. According to what has been said, the conceptual model and research questions are presented as follows. 


\section{The Research Conceptual Model}

\begin{tabular}{|c|c|}
\hline $\begin{array}{c}\text { Predictor variable of Ali's } \\
\text { cultur al behavior } \\
\text { Piety and piousness } \\
\text { 1. God-centerdness and } \\
\text { monotheism } \\
\text { 2. Promiting the necessity } \\
\text { of obeying deivine } \\
\text { sovereignty } \\
\text { 3. Expediency in Islamic } \\
\text { culture } \\
\text { 4. Meritocracy }\end{array}$ & $\begin{array}{r}\text { Criterion variable of } \\
\text { cultural policy }\end{array}$ \\
$\begin{array}{r}\text { Problem seeking, policy } \\
\text { formulation, legitimization, } \\
\text { policy implementation and } \\
\text { evaluation }\end{array}$ \\
\end{tabular}

\section{Research Questions}

1. Does piety and piousness (Imam Ali's biography) have an effect on cultural planning in Payame Noor universities in District 8?

2. Does God-centeredness and monotheism (Imam Ali's biography) have an effect on cultural planning in Payame Noor universities in District 8?

3. Does the promotion of the need to follow the divine sovereignty (Imam Ali's biography) have an effect on cultural policy-making in Payame Noor universities in District 8 ?

4. Does expediency in Islamic culture (Imam Ali's biography) have an impact on cultural planning in Payame Noor universities in District 8?

5. Does meritocracy (Imam Ali's biography) have an effect on cultural policy-making in Payame Noor universities in District 8 ?

\section{Materials and Methods}

This research is descriptive-correlational in nature and method and practical in terms of purpose. Data collection tools were two questionnaires: piety and piousness (18 questions) and policymaking questionnaire (57 questions). The statistical population of this research consisted of two groups: 1.The statistical population of subject-aware experts: The statistical population of this research in the process of model making is subject-aware experts. The experts of the present study are university professors and specialists in the field of management and Islamic management who have participated in the construction of the model through Delphi technique. The method of determining the sample size of experts has been a judgmental selection whose number is unknown. 2. The statistical population of officials of universities' cultural affairs and the clergy and professors of the Islamic Education Department of Payame Noor universities, District 8: during the research, the number of officials of cultural affairs and the clergy and professors of the Islamic Education Department was 102 individuals. Structural validity was used to ensure the validity of the questionnaires. Sample size of subject-aware experts: The sample size of experts was determined as a total of 30 people. The sample size of the person in charge of cultural affairs of universities and clerics and professors of Islamic education Department of Payame Noor universities, District 8: In this group due to the limited statistical population, the census method was used and all the individuals in the statistical population were selected as a statistical sample. The results of the questionnaire were analyzed in SPSS 21 statistical software as well as Smart PLS software. The collected materials in the questionnaires were analyzed based on SPSS software. Content validity ratio (CVR) and content validity index (CVI) were used 
to determine the validity of the questionnaires. Finally, Cronbach's alpha coefficient and composite reliability (CR) were used to determine the reliability of the questionnaires (Table 1).

Table 1.

Reliability of the Research Structures

\begin{tabular}{llc}
\hline Component & Cronbach's alpha & CR \\
\hline God-centeredness and monotheism & 0.924 & 0.921 \\
\hline $\begin{array}{l}\text { Promoting the necessity of obeying di- } \\
\text { vine sovereignty }\end{array}$ & 0.907 & 0.905 \\
\hline Expediency in Islamic culture & 0.922 & 0.920 \\
\hline Meritocracy & 0.847 & 0.845 \\
\hline Piety and piousness & 0.962 & 0.961 \\
\hline Recognition & 0.952 & 0.950 \\
\hline Formulation (codification) & 0.879 & 0.877 \\
\hline Legitimization & 0.888 & 0.887 \\
\hline Implementation & 0.915 & 0.912 \\
\hline Evaluation & 0.916 & 0.915 \\
\hline Cultural policy & 0.954 & 0.993
\end{tabular}

According to the table, the coefficients are higher than the minimum value of 0.7 , which indicates the appropriate reliability of the reagents. Descriptive and inferential statistics were also used to analyze the data. In the descriptive statistics of the research, the research variables such as mean, standard deviation and variance and demographic variables such as gender, age, educational status were studied; Then, in inferential statistics, in order to check the validity of the questionnaire, confirmatory factor analysis was used and in order to check the research hypotheses, structural equation modeling (SEM) method was used with the help of Smart PLS 3 software.

\section{Results}

Descriptive Statistics of the Research Variables

In the following, a descriptive statistic of research variables such as mean, standard deviation and variance is presented (Table 2). 


\section{Table 2.}

Descriptive Statistics of Research Variables

\begin{tabular}{|c|c|c|c|c|c|c|c|c|c|c|c|}
\hline $\begin{array}{l}\text { Varia- } \\
\text { bles }\end{array}$ & $\begin{array}{l}\text { Piety } \\
\text { and } \\
\text { pious- } \\
\text { ness }\end{array}$ & $\begin{array}{c}\text { God- } \\
\text { cen- } \\
\text { te- } \\
\text { red- } \\
\text { ness } \\
\text { and } \\
\text { mono- } \\
\text { the- } \\
\text { ism }\end{array}$ & $\begin{array}{l}\text { Promot- } \\
\text { ing the } \\
\text { necessi- } \\
\text { ty of } \\
\text { obeying } \\
\text { divine } \\
\text { sover- } \\
\text { eignty }\end{array}$ & $\begin{array}{l}\text { Expedi- } \\
\text { ency in } \\
\text { Islamic } \\
\text { culture }\end{array}$ & $\begin{array}{l}\text { meritoc- } \\
\text { racy }\end{array}$ & $\begin{array}{l}\text { Cul- } \\
\text { tural } \\
\text { policy }\end{array}$ & $\begin{array}{l}\text { Recog } \\
\text { nition }\end{array}$ & $\begin{array}{l}\text { Formu- } \\
\text { lation }\end{array}$ & $\begin{array}{l}\text { Legitimi- } \\
\text { zation }\end{array}$ & $\begin{array}{l}\text { Implemen- } \\
\text { tation }\end{array}$ & $\begin{array}{l}\text { Eval- } \\
\text { uation }\end{array}$ \\
\hline Numbers & 102 & 102 & 102 & 102 & 102 & 102 & 102 & 102 & 102 & 102 & 102 \\
\hline Mean & 3.4261 & $\begin{array}{c}3.368 \\
1\end{array}$ & 3.3548 & 3.4608 & 3.5209 & 3.4709 & 3.3739 & 3.5625 & 3.5931 & 3.3894 & 3.4356 \\
\hline Median & 3.5714 & $\begin{array}{c}3.357 \\
1\end{array}$ & 3.2857 & 3.4286 & 3.4333 & 3.4000 & 3.1429 & 3.5000 & 3.6000 & 3.3857 & 3.5714 \\
\hline $\begin{array}{l}\text { Standard } \\
\text { deviation }\end{array}$ & $\begin{array}{c}0.6935 \\
0\end{array}$ & $\begin{array}{c}0.640 \\
78\end{array}$ & 0.75957 & 0.66031 & 0.62960 & $\begin{array}{c}0.6912 \\
6\end{array}$ & $\begin{array}{c}0.7449 \\
0\end{array}$ & 0.69291 & 0.63014 & 0.65144 & $\begin{array}{c}0.7912 \\
9\end{array}$ \\
\hline Variance & 0.481 & 0.411 & 0.577 & 0.436 & 0.396 & 0.478 & 0.555 & 0.480 & 0.397 & 0.424 & 0.626 \\
\hline $\begin{array}{l}\text { Skew- } \\
\text { ness }\end{array}$ & -0.194 & -0.046 & -0.130 & 0.331 & 0.151 & -0.013 & -0.002 & -0.002 & 0.228 & 0.133 & -0.063 \\
\hline $\begin{array}{c}\text { Standard } \\
\text { error of } \\
\text { skew- } \\
\text { ness }\end{array}$ & 0.239 & 0.239 & 0.239 & 0.239 & 0.239 & 0.239 & 0.239 & 0.239 & 0.239 & 0.239 & 0.239 \\
\hline Kurtosis & 0.130 & -0.042 & -0.131 & -0.368 & 0.505 & 0.143 & 0.693 & 0.086 & 0.225 & 0.204 & -0.650 \\
\hline $\begin{array}{l}\text { Standard } \\
\text { error of } \\
\text { kurtosis }\end{array}$ & 0.474 & 0.474 & 0.474 & 0.474 & 0.474 & 0.474 & 0.474 & 0.474 & 0.474 & 0.474 & 0.474 \\
\hline $\begin{array}{l}\text { Mini- } \\
\text { mum }\end{array}$ & 1.57 & 2.00 & 1.29 & 2.00 & 1.67 & 2.00 & 1.14 & 1.50 & 2.00 & 2.00 & 2.00 \\
\hline $\begin{array}{l}\text { Maxi- } \\
\text { mum }\end{array}$ & 5.00 & 5.00 & 5.00 & 5.00 & 5.00 & 5.00 & 5.00 & 5.00 & 5.00 & 5.00 & 5.00 \\
\hline
\end{tabular}

Inferential Statistics and Studying Research Hypotheses

Determining the Normality or Abnormality Using Kolmogorov-Smirnov Test

Before testing the research hypotheses, it must be ensured first that the variables are normal. If the significance level is more that $0.05 \%$, the variable is normal. Otherwise, the data is abnormal. Therefore, according to (Table 3) all variables are abnormal.

Table 3.

The Results of Kolmogorov-Smirnov Test to Study the Assumption of Being Normal or Abnormal

\begin{tabular}{llll}
\hline Variables & Sample size & Test statistic1.878 & P-value \\
\hline $\begin{array}{l}\text { God-centeredness and } \\
\text { monotheism }\end{array}$ & 102 & 0.000 \\
\hline $\begin{array}{l}\text { Promoting the neces- } \\
\text { sity of obeying divine }\end{array}$ & 102 & 1.413 & 0.000 \\
\hline
\end{tabular}


sovereignty

Expediency in Islamic 102

1.555

0.001

culture

\begin{tabular}{lccc}
\hline Meritocracy & 102 & 1.709 & 0.000 \\
\hline Piety and piousness & 102 & 1.600 & 0.001 \\
\hline Recognition & 102 & 1.330 & 0.000 \\
\hline $\begin{array}{l}\text { Formulation (codifica- } \\
\text { tion) }\end{array}$ & 102 & 2.351 & 0.000 \\
\hline Legitimization & 102 & 1.166 & 0.002 \\
\hline Implementation & 102 & 1.045 & 0.000 \\
\hline Evaluation & 102 & 1.598 & 0.000 \\
\hline Cultural policy & 102 & 1.654 & 0.000
\end{tabular}

Correlation between the Studied Variables

Since one of the assumptions of using causal relationships is the absence of multiple linear relationships between variables, the correlation coefficients between the study variables were calculated before causal analysis to investigate the absence of multicolinearity relationships between variables. The correlation coefficient indicates the intensity of the relationship as well as the type of relationship (inverse or direct). According to the research findings, all correlations were less than 0.8 , so the existence of multicolinearity relationships between variables is not confirmed.

Validity

Convergent Validity

The partial least square of average variance extracted (AVE) is used to calculate the convergent validity of the structures.

\section{Table 4.}

Convergent Validity of Structures

\begin{tabular}{ll}
\hline Variable & $\begin{array}{l}\text { Average } \\
\text { (AVE) }\end{array}$
\end{tabular}

Piety and piousness 0.5128

God-centeredness and monotheism 0.5285

Promoting the necessity of obeying divine sovereignty $\quad 0.6219$

Expediency in Islamic culture $\quad 0.5657$

\begin{tabular}{lc}
\hline Meritocracy & 0.6138
\end{tabular}

$\begin{array}{lc}\text { Cultural policy } & 0.7910\end{array}$

$\begin{array}{ll}\text { Recognition } & 0.7136\end{array}$ 
Formulation (codification)

Legitimization

Implementation

Evaluation
0.7577

0.7365

0.7243

0.7651

As it can be seen in (Table 4), AVE value for the variables of this study is between 0.8955 and 0.5128 , which is higher than the minimum value of 0.5 , which indicates the appropriate convergent validity of structures.

Confirmatory Factor Analysis for the Research Variable Questions in Standard Estimation

Before entering the stage of testing research hypotheses, it is necessary to ensure the accuracy of questions related to research variables, therefore, confirmatory factor analysis is used (Figure 1).

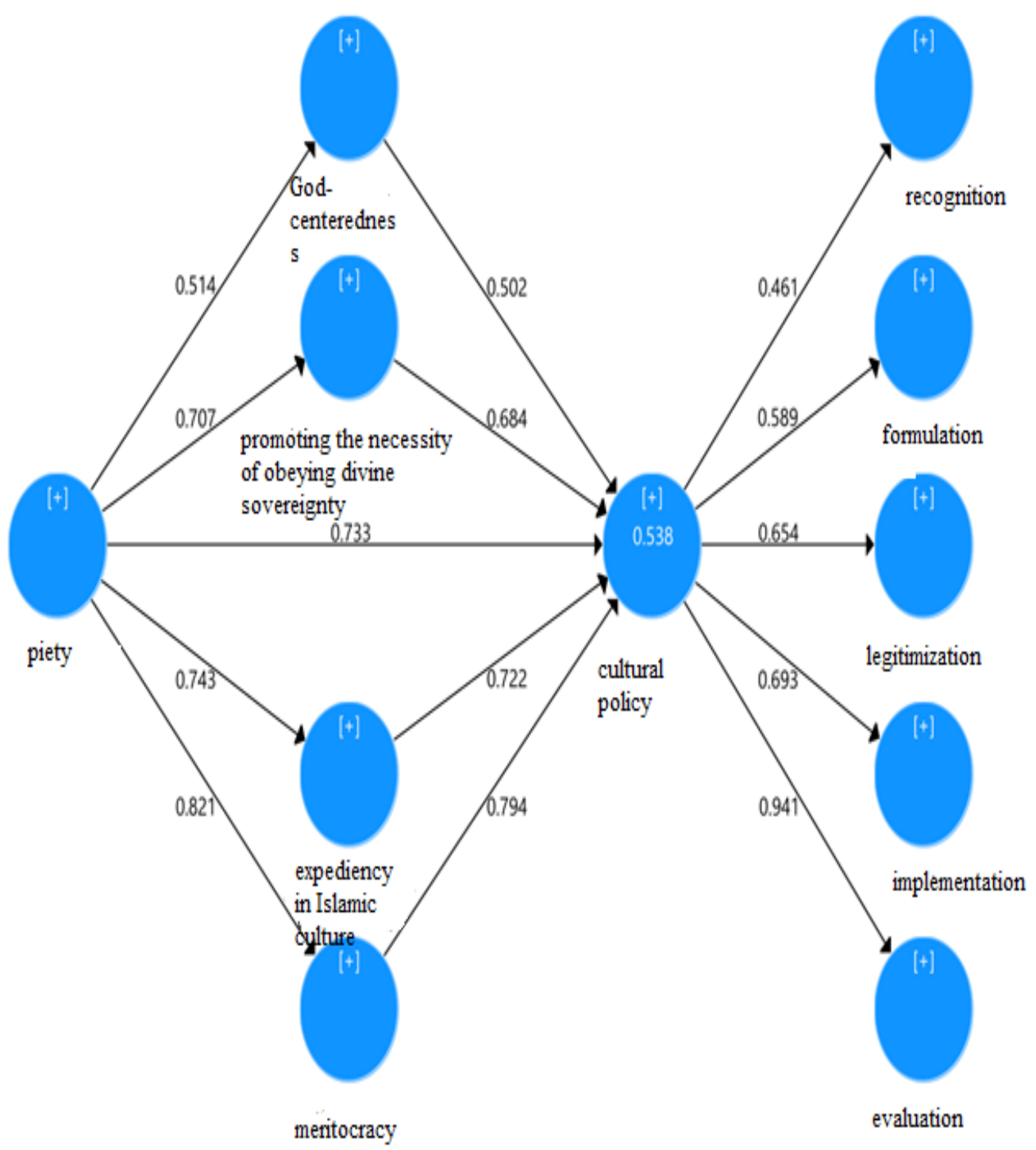

Figure 1. Standard Numbers of Research Questions 
Factorized loadings are really important in interpreting the results of factor analysis. These loadings indicate the correlation between each observed variable (questions) and its related factors. Depending on how the researcher considers accuracy to remove the questions, the criterion values are presented from 0.5 to 0.7 for the factor loadings, but the minimum value is 0.4. This means that questions with factor loadings less than 0.3 are not sufficient to remain in the model and they should be removed. As you can see in the model, all numbers are above 0.3, so no questions are deleted.

Confirmatory Factor Analysis for Research Variable Questions for Significant Numbers

The values of this graph measure the relationship between latent (unobserved) variables in a significant way.

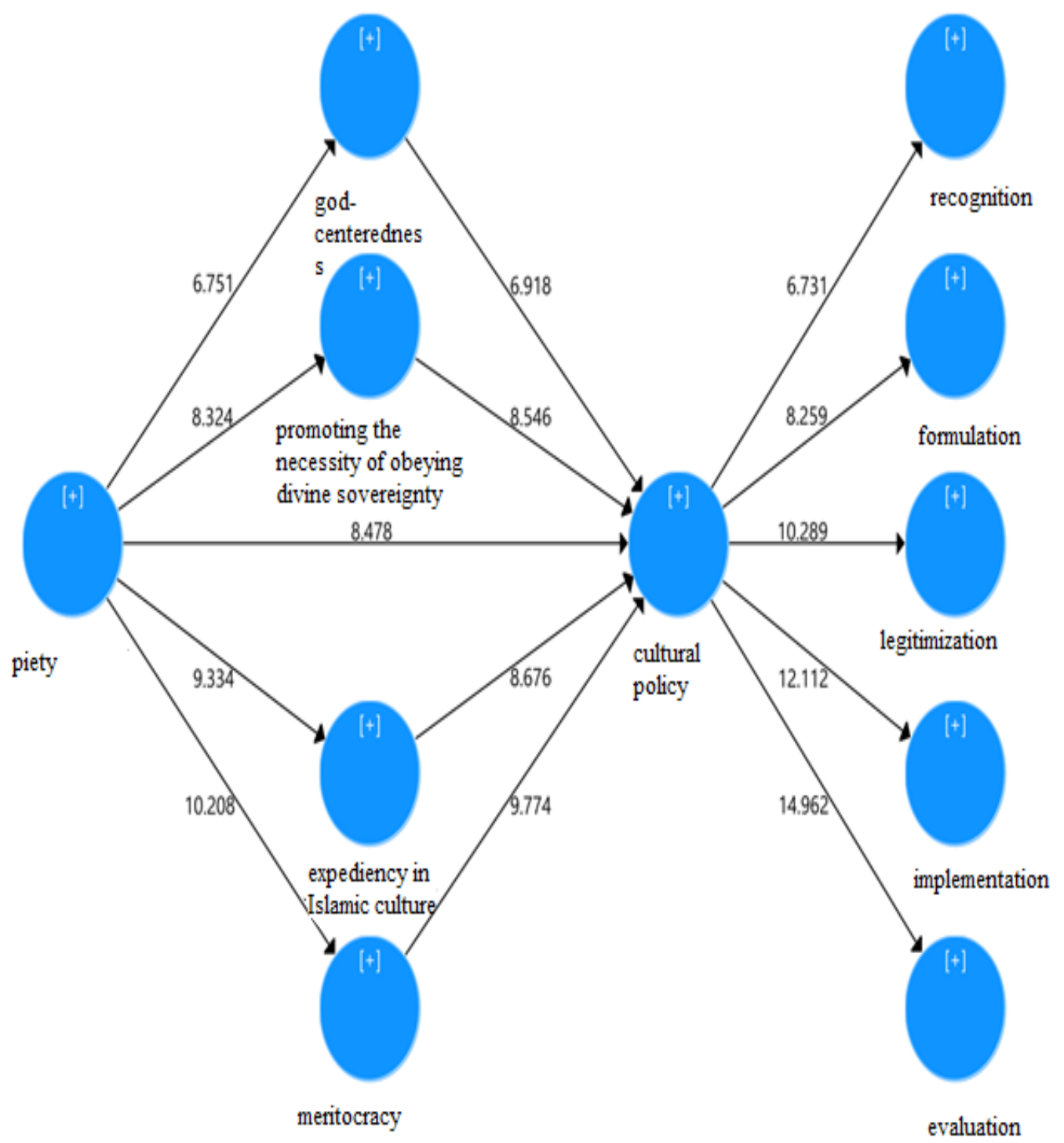

Figure 2. Significant Numbers of Research Questions

According to (Figure 2), if the value of $t$ is between +1.96 and -1.96 , the relationships between the variables will not be significant at the $95 \%$ confidence level, and if the value of $t$ is greater than +1.96 Or less than -1.96 , the relationships between the variables will be significant at the $95 \%$ confidence level, so if the value of the $\mathrm{T}$ statistic is greater than 1.96 , it indicates the correctness of the relationship between the structures and thus confirmation of the research hypotheses are at the $95 \%$ confidence level, based on which all the relationships in the model are significant. 
Finally, Goodness of Fit (GOF) was used to fit the model. Goodness of fit criterion for the overall fitness of the model was calculated 0.60, which indicates a strong fitness of the model.

\section{Testing the Research Hypotheses}

The main question: Does piety and piousness (Imam Ali's biography) impact on cultural policy of Payame Noor universities in District 8?

According to the coefficient of variable path of piety and piousness (Imam Ali's biography) on cultural policy of Payame Noor universities in District 8, which was 0.733 and also the t-statistic was 8.478 , it can be said that piety and piousness (Imam Ali's biography) has a positive and significant impact on cultural policy of Payame Noor universities in District 8. A summary of the structural equation modeling results is presented in (Table 5).

\section{Table 5.}

The Results of Modeling the Research Structural Equations

\begin{tabular}{|c|c|c|c|c|}
\hline $\begin{array}{l}\text { Relationships of } \\
\text { research varia- } \\
\text { bles }\end{array}$ & $\begin{array}{l}\text { Significant num- } \\
\text { bers (t-value) }\end{array}$ & $\begin{array}{l}\text { Direct effect } \\
\text { (R) }\end{array}$ & $\begin{array}{l}\text { Wide (total) } \\
\text { effect }\end{array}$ & Result \\
\hline $\begin{array}{l}\text { Piety and pious- } \\
\text { ness (Imam Ali's } \\
\text { biography) on } \\
\text { cultural policy }\end{array}$ & 8.478 & 0.733 & 0.733 & $\begin{array}{l}\text { Positive and sig- } \\
\text { nificant }\end{array}$ \\
\hline
\end{tabular}

According to (Table 5), all the coefficients of factor loadings are higher than 0.4, which show the appropriateness of this model.

Sub-question 1: Does God-centeredness and monotheism (Imam Ali's biography) affect cultural policy-making in Payame Noor universities in District 8?

With regard to the path coefficient of God-centeredness and monotheism on cultural policy-making in Payame Noor universities of District 8, which was 0.502 with t-statistic of 6.918, it can be said that God-centeredness and monotheism has a positive and significant effect on cultural policy-making of Payame Noor universities in District 8. A summary of the structural equation modeling results is presented in (Table 6):

Table 6.

Results of Structural Equations Modeling of the Research

\begin{tabular}{ccccc}
\hline $\begin{array}{c}\text { Relationships of } \\
\text { research varia- } \\
\text { bles }\end{array}$ & $\begin{array}{c}\text { Significant num- } \\
\text { bers (t-value) }\end{array}$ & $\begin{array}{c}\text { Direct effect } \\
\text { (R) }\end{array}$ & $\begin{array}{c}\text { Wide (total) } \\
\text { effect }\end{array}$ & Result \\
\hline $\begin{array}{c}\text { God- } \\
\text { centeredness } \\
\text { and monotheism } \\
\text { (Imam Ali's bi- } \\
\text { ography) on cul- } \\
\text { tural policy- } \\
\text { making }\end{array}$ & 6.918 & 0.502 & 0.502 & $\begin{array}{c}\text { Positive and sig- } \\
\text { nificant }\end{array}$ \\
\end{tabular}

As it can be seen in (Table 6), it is obvious that all factor loading coefficients are greater than 0.4 , which indicated the appropriateness of this model. 
Sub-question 2: Does the promotion of the need to follow the divine sovereignty (biography of Imam Ali) have an effect on cultural policy-making in Payame Noor universities of District 8?

Considering the path coefficient of promoting the necessity of following the divine sovereignty variable (biography of Imam Ali) on the cultural policy-making in Payame Noor universities of District 8, which is 0.694 and also the t-statistic is 8.545 , it can be said that promoting the necessity of following the divine sovereignty (Imam Ali's biography) has a positive and significant effect on cultural policy-making in Payame Noor universities of District 8. A summary of the structural equation modeling results is presented in (Table 7):

Table 7.

Results of Implementing the Research Structural Equations Modeling

\begin{tabular}{ccccc}
\hline $\begin{array}{c}\text { Relationships of } \\
\text { research varia- } \\
\text { bles }\end{array}$ & $\begin{array}{c}\text { Significant num- } \\
\text { bers (t-value) }\end{array}$ & $\begin{array}{c}\text { Direct effect } \\
\text { (R) }\end{array}$ & $\begin{array}{c}\text { Wide (total) } \\
\text { effect }\end{array}$ & Result \\
\hline $\begin{array}{c}\text { Promoting the } \\
\text { need to follow } \\
\text { divine sover- } \\
\text { eignty (biog- } \\
\text { raphy of Imam }\end{array}$ & 8.545 & 0.694 & 0.694 & $\begin{array}{c}\text { Positive and sig- } \\
\text { nificant }\end{array}$ \\
$\begin{array}{c}\text { Ali) on cultural } \\
\text { policy-making }\end{array}$ & & & & \\
\hline
\end{tabular}

According to (Table 7), all the coefficients of factor loadings are greater than 0.4 , which show the appropriateness of the model.

Sub-question 3: Does expediency in Islamic culture (Imam Ali's biography) affect cultural policy-making in Payame Noor universities of District 8?

According to the path coefficient of the variable of expediency in Islamic culture (biography of Imam Ali) on policy of culture in Payame Noor universities of District 8 , which is 0.722 and the t-statistic is 8.676, it can be said that expediency in Islamic culture (biography of Imam Ali) has a positive and significant effect on cultural policy of Payame Noor universities in district 8. A summary of the structural equation modeling results is presented in (Table 8):

Table 8.

Results of Implementing the Research Structural Equations Modeling

\begin{tabular}{ccccc}
\hline $\begin{array}{c}\text { Relationships of } \\
\text { research varia- } \\
\text { bles }\end{array}$ & $\begin{array}{c}\text { Significant num- } \\
\text { bers (t-value) }\end{array}$ & $\begin{array}{c}\text { Direct effect } \\
(\mathbf{R})\end{array}$ & $\begin{array}{c}\text { Wide (total) } \\
\text { effect }\end{array}$ & Result \\
\hline $\begin{array}{c}\text { Expediency in } \\
\text { Islamic culture } \\
\text { (biography of }\end{array}$ & 8.676 & 0.722 & 0.722 & $\begin{array}{c}\text { Positive and sig- } \\
\text { nificant }\end{array}$ \\
$\begin{array}{c}\text { Imam Ali) on } \\
\text { policy of culture }\end{array}$ & & & & \\
\hline
\end{tabular}

As it can be seen in (Table 8), all the coefficients of factor loadings are greater than 0.4 , which indicate the suitability of the model.

Sub-question 4: Does meritocracy (Imam Ali's biography) affect the cultural policy in Payame Noor universities in District 8 ? 
According to the path coefficient of meritocracy variable (Imam Ali's biography) on cultural policy in Payame Noor universities of District 8, which is 0.794 and also t-statistic is 9.774, it can be said that meritocracy (Imam Ali's biography) has a positive and significant effect on cultural policy of Payame Noor universities in District 8.

A summary of the structural equation modeling results is presented in (Table 9):

Table 9.

Results of Modeling the Structural Equations of the Research

\begin{tabular}{ccccc}
\hline $\begin{array}{c}\text { Relationships of } \\
\text { research varia- } \\
\text { bles }\end{array}$ & $\begin{array}{c}\text { Significant } \\
\text { numbers (t- } \\
\text { value) }\end{array}$ & $\begin{array}{c}\text { Direct effect } \\
\text { (R) }\end{array}$ & $\begin{array}{c}\text { Wide (total) } \\
\text { effect }\end{array}$ & Result \\
\hline $\begin{array}{c}\text { Meritocracy (bi- } \\
\text { ography of }\end{array}$ & 9.774 & 0.794 & 0.794 & $\begin{array}{c}\text { Positive and sig- } \\
\text { nificant }\end{array}$ \\
$\begin{array}{c}\text { Imam Ali) on } \\
\text { cultural policy }\end{array}$ & & & & \\
\hline
\end{tabular}

According to (Table 9), all the coefficients of factor loadings are greater than 0.4 , which show the suitability of the model.

\section{Discussion}

The main purpose of this study was to investigate the effect of piety (Imam Ali biography) on cultural policy in Payame Noor universities of District 8 . The data were analyzed by structural equation modeling. The results of structural equation modeling showed that the research model has a goodness of fit. Considering the path coefficient of piety variable (Imam Ali biography) on cultural policy of Payame Noor universities in District 8, which is 0.733 and t-statistic is 8.478 , it can be said that piety (Imam Ali biography) has a positive and significant effect on cultural policy of Payame Noor universities in District 8. Furthermore, all aspects of piety (Godcenteredness and monotheism, promoting the need to obey divine sovereignty, expediency and meritocracy) have an impact on cultural policy and improve cultural policy-making.

Undoubtedly, one of the influential factors in the policies of a society is ethics and piety, the presence or absence of which in the policies of a country can lead to many problems and anomalies. If we pay attention to the Quran's analysis of piety and its benefits and effects, it becomes clear that how piety can be effective and useful in policy-making; Because many of the problems of human societies are due to the fact that the officials and social and political leaders who play a key role in decision-making and policy-making are not pious. Piety as a factor of management, rule of law, restraint and internal control, awakened human conscience, encouraging charity and a healthy and moral nature and encouraging norms and many other matters and issues, the most important factor is in the field of political policy that should be considered (Lakzai \& Nabatian, 2013). In Islamic texts, piety is mentioned as a valuable goal. "Piety" has been introduced in verses and hadiths as the cause of human happiness and salvation and one of the purposes of the revelation of the Quran and its observance has been emphasized a lot and without piety, ethics and faith are not meaningful. Imam Ali said: "Piety is the leader of morality" and "Faith without piety is not beneficial" (Goldar et al., 2017). Political piety is not onesided either. In other words, the mere existence of this feature in the politician will not lead to the perfection of society, but the people of society must also have the culture and understanding of using a pious ruler. Otherwise, a ruler who is at the highest level of growth and perfection of political piety will be disappointed and his heart will be broken, as Imam Ali suffered from the unfaithful people of Kufa. On the other hand, the disruption in the political piety of the politician undoubtedly has its effect on the society and reduces the growth, perfection and coordina- 
tion of its people. In general, it can be said that political and personal piety is one of the influential elements in the political life of Imam Ali. In a society where political piety is observed among the officials, the people of the society follow social piety in other issues and the society moves towards security and peace. "Yes, if you remain patient and conscious of Allah and the enemy come upon you in rage, your lord reinforce you with five thousand angles having marks of distinction. God did not point it but as a good news for you and to reassure with it your hearts; and victory comes only from Allah, the All-mighty, the All-wise. "Indeed the God-wary will be aimed gardens and springs". The angels say to them: Enter it in peace and safety. Although these verses speak of peace, security and comfort in the hereafter and in eternity, it cannot be forgotten that God has considered peace and eternal comfort as the natural result of piety; therefore, naturally, if someone in the world seeks security and peace or comfort, he should observe piety. This is well stated in other verses; "And if only the people of the cities had believed and feared Allah, We would have opened upon them blessings from the heaven and the earth; but they denied the messengers, so we seized them for what they were earning" (Majlesi, 1984).

\section{Conclusion}

The enjoyment of human societies from the development of various heaven and earth blessings, as well as material and spiritual blessings depend on the piety of societies and introduces it as a natural result of piety. On this basis, it can be said that achieving civilization and comfort in the world can only be achieved through piety, otherwise we cannot talk about comfort, although it seems that some people far from this element have reached to comfort, if one looks precisely it becomes clear that it is an illusion or that they observe a kind of social and political piety that they have achieved this relative peace and comfort, because God never ruin and waste the reward, and if a society observes political and social piety, even it is an infidel, it will enjoy the blessings of the same piety and its effects in the world. On the other hand, in any society where political and social piety such as avoiding oppression and encroachment on the rights of others, inciting riots and breaking the law and strengthening abnormalities and abandoning the enjoining good and forbidding wrong are not observed, that society cannot experience peace and comfort and chaos encompasses all its pillars and society will be collapsed from inside (Lakzai \& Nabatian, 2013). If the political and social decision-makers lie to the people in order to maintain their position, because they have turned away from piety and put it aside, they have incited social distrust that its natural result is social divergence and capitals of that society will be lost. Thus, what has been mentioned as political piety actually refers to the observance of moral principles and norms and human rules and values that a Muslim policymaker pays attention to them in practice. Any person who is somehow related to the sphere of power in the field of politics, by considering the temptations and challenges that this sphere may have for him, he needs a degree of piety to be safe from falling into the valley of destruction (Mohammadi Gharasoui, 2013). Therefore, by obeying the behavior of Imams, especially Imam Ali, the framework for institutionalizing moral policy and creating political piety among the officials can be drawn according to the requirements of today. The most important and largest center of divine tests is social and political affairs, especially the field of policy-making and decision-making. It is in this area that people reveal their truth, and only those who have tried in self-improvement and catharsis can pass the tests with political and social piety. Among these, social tests are the most important tests for everyone; because everyone shows his true self in interaction with others. It is in these cases that a person reflects on how successful he has been in self-improvement and catharsis and enjoying divine piety.

\section{References}

Komilifard M. \& Tahmasebi Blookabad R. \& Hamzehpour M. (2017), Study and Analysis of the Steps of the Cultural Policy System in the Islamic Revolution of Iran, Journal of the Islamic Revolution (Scientific-Research), 7(2): 23-38.

Poor Ezat A. (2014), Fundamentals of Knowledge of Ruling Government, Tehran: Samt, 7(2): 23-38. 
Smith Kevin B. \& Christopher W. (2009), The Public Policy Theory Priemer, west view press, 7(2): 23-38.

Mohammadi Gharasoui A. (2013), Planning, Policy, Decision Making, Control, Fundamentals of Organization and Management, Marvdasht: Journal of the Educational Center in Mani Shahid Motahari, 16(3): 189-211.

Goldar Z. \& Amiri M. \& Gholipoursoteh R. \& Moazami M. (2017), Designing a Conceptual Framework for Beneficiaries' Engagement in Public Policy, Auditing Knowledge, 17(66): 81-105.

Rezaian A. (2011), Fundamentals of Organization and Management, Tehran: Samt Publications, 9(3): 341-352.

Alvani M. \& Sharifzadeh F. (2011), The Process of Public Policy-Making, Eighth Edition, Tehran: Allameh Tabatabai University Press, 9(3): 341-352.

Alvani M. \& Behzad P. \& Mehraban H. (2014), A Review of Policy-Making Models in the Higher Education System, Parliament and Research, 15(59): 390-412.

Khanifar H. \& Agdaghi M. (2015), Conceptual Model of the Levels of Influence of Islamic Teachings on Cultural Policy, Socio-cultural Knowledge, 22(5): 45-62.

Afjeh A. \& Naqi Porfar V. \& Jafarpour M. (2014), Presenting a Model for Conducting Basic Research in the Field of Islamic Management Studies (Case study: Distributive Justice in the Organization), Basij Strategic Studies, 8(2): 100-116.

Askarian G. (2011), Tricks of Time, Tehran: Mousavi Publications, 11(3): 33-40.

Zeraat A. (2017), Ways of Islamization of Universities, Islamic University, 17(7): 115-128.

Tamimei Amedi A, (1980), Ghorar Al-Hekam, Qom: Society of Lecturers of Qom Seminary, Islamic Press; 1995. Vol.4 p.198.

Gorbanizadeh V. \& Sharifzadeh F. \& Hosseinpour D. \& Moravvaj M. (2017), Presenting the Model of Policy of Cultural Organizations (Case study: Institute for the Intellectual Development of Children and Younger Adults), Quarterly Journal of Public Policy, 3(3): 61-78.

Sakaran A. (2011), Research Methods in Management, Translated by Mohammad Saebi and Mahmoud Shirazi, Tehran: Publications of the Institute for Management and Planning Studies, seventh edition, 6(2): 147-161.

Bardach E. (1997), The implemention game: What happens afteer a bill becomes a law, Boston, MA: Colonial inc, 6(4): 261-280.

Makinde T. (2010), "Problem of policy implementation in developing nations: The Nigerian experience", J. SOC. Sci., 11(1): 63-69.

Konsult A. (2009), "Barriers to Implementation", The Kon SULT Knowledgebase, available, 16(3): 296-307.

Ghoshal S. (2005), Bad Management Theories Are Destroying Good Management Practices, Academy of Management Learning \& Education, 4(1): 75-91.

Amadi A. (2006), Gharr al-Hakam, translated by Mohammad Ali Ansari, edited by Mehdi Ansari Qomi, 4(1): 75-91.

Ayoubi H. (2010), Cultural Policy in France: Government and Art, Tehran: Samt, 15(2): 156166.

Lakzai N. \& Nabatian M. (2013), Cultural Security from the Perspective of Shia Jurisprudence, Strategic Studies of the Sixteenth Year of Winter, 39(3): 39-50.

Majlesi M. (1984), Bihar al-Anwar. 2nd ed. Tehran: Islamyah; p.2-3. 